We found no clear, unambiguous support for the merger. One benefit that surprised senior staff working on higher education was that the merger facilitated the formulation of the higher education ten-year strategic plan. However, now that the Blueprint has been completed and adopted, those concerned find that separation is preferable for implementation and focus.

The potential institutional instability resulting from the merger (or, for that matter, from any reorganization of government structures) was mitigated by the existence of autonomous agencies performing major functions, as well as by the fact that the universities are autonomous.

Perhaps the most surprising finding of our work is the near-total absence of any systematic analysis of the frequent phenomenon of ministerial mergers and demergers in the sector of education. Does this lack of interest constitute a recognition that mergers/demergers are of little consequence, or, rather, does it point to a general lack of concern for the institutional, organizational, and managerial dimensions of the sector? The latter would be highly worrisome given the developmental, social, financial, and political importance of the education sector.

\section{Christian Higher Education's Place within Private Higher Education}

\section{Daniel Levy}

Daniel Levy is distinguished professor, Department of Educational Administration and Policy Studies, State University of New York at Albany, US. E-mail:dlevy@albany.edu.

$\mathrm{P}$ ROPHE (Program for Research on Private Higher Education) has a regular column in IHE and occasionally a Special Focus topic with multiple articles. This issue's topic is Christian Higher Education.

As many IHE articles over recent years testify, private higher education (PHE) has grown immensely worldwide. Although most of the articles have dealt with PHE rather generically, others have focused on some particular type of PHE. This Special Focus section highlights Christian higher education (CHE). The section's geographical coverage is broad, as both this introductory piece and Glanzer's piece are global in scope, and Carpenter's is regional (Africa).

$\mathrm{CHE}$ in this Special Focus refers mostly to contemporary growth, international settings, and Protestant as well as Catholic institutions. (Orthodox Christianity has not much joined the move into higher education.) Although the Special Focus pieces find variation within CHE (by region, country, and institution), they also identify enough defining CHE realities to make CHE a viable category for analysis.

To open the Special Focus section, this introductory piece places CHE within the context of PHE. More specifically, it indicates how CHE is a type of "identity" PHE. By far the most common form of identity presence in higher education is religious, though ethnic and women's colleges also have a presence. In the nineteenth, and late into the twentieth century, the growing religious type was often Catholic. But the Protestant component of the contemporary $\mathrm{CHE}$ surge augments the pluralist nature of the religious proliferation. (Some echo is heard on the growth of Islamic colleges and universities, though these are often public as well as private and, in any case, are beyond the scope of this Special Focus.)

The coherence of the CHE category manifests itself in two vital elements at the forefront of each of this Special Focus's articles: growth and challenges.

\section{GROWTH}

Like other identity institutions, CHE institutions emerge to foster the interests of a group. There is a strong promotional side, but also often a defensive side, as a secularizing society and higher education system threaten (intentionally or not) the religious presence in higher education. Even a majority among the general population may find itself only a small minority force in a country's public higher education sector. The religious motivation for growth may be rather narrow, or broadened to include social missions such as serving the poor. Alongside distinctly religious motivations, however, religious higher education institutions sometimes grow from dynamics found also in PHE's nonidentity sectors. From their outset, most religious institutions declare academic missions as well. Over time, CHE institutions seek to build enrollment for the tuition it brings, while governments push them to help expand higher education access. On the other hand, some academically and socially privileged CHE institutions grow as students escape the political and other problems that plague the public sector in many countries. Thus, in CHE as in identity institutions generally, growth comes from a combination of distinctive group causes and nondistinctive causes, seen elsewhere in PHE.

"Academic drift," that common higher education reality in which institutions ascend in their level (including ascension upward into higher education), plays itself out in vivid form in CHE. Seminaries or other institutions training religious leaders and concentrating on theology, become universities offering nonreligious fields alongside religious ones. The motivation may be to reach out to soci- 
ety or marry faith and science, but it may include financial, expansionist, or status motivations widely at play in private (and public) institutions.

The contemporary surge of CHE is part of the broader ongoing PHE surge, but not of a generalized religious surge. Catholic higher education, in parts of the world the most important identity type in the ninteenth and twentieth centuries, has been more in descent than ascent. The Catholic wing of today's CHE surge is largely in new institutions and in regions (Africa looming large here), with only a small prior Catholic or other private presence. In Latin America, contrasts between traditional Catholic universities and new Protestant or Evangelical ones are striking.

The extent of the global CHE surge is difficult to quantify-in particular in enrollment. The phenomenon is exaggerated by the striking number of institutions, as many of them, especially Protestant ones, are small. Nonetheless, authors can point to more than a few large CHE institutions. The CHE surge is more potent in the developing than developed world, notwithstanding important exceptions in Japan and South Korea.

\section{There is a strong promotional side, but also often a defensive side, as a secular- izing society and higher education sys- tem threaten (intentionally or not) the religious presence in higher education.}

\section{Challenges}

Unfortunately for the CHE institutions, they are vulnerable to two major kinds of challenges. One kind is rather general to PHE institutions. The other is especially fundamental to identity institutions. Both threaten enrollment size, but the latter especially threatens dilution of core mission.

Just as CHE grows from some causes similar to those behind other PHE growth, so it is vulnerable to challenges that face most PHE institutions, with particulars sometimes involving religion. A national swing to the political left may bring increased regulation and even hostility, especially where the left sees religion as regressive or at least basically irrelevant to higher education. CHE legitimacy may be shaky on grounds of both academic quality, as is common for PHE, or isolation from unifying public national missions. Finance is a common threat for private institutions and, as is common with identity institutions, most CHE institutions get little or no public funding. Academic drift stemming from aspirations to meet quality and status expectations pushes against focused priority on original re- ligious mission.

At the same time and in several ways, the very forces that lead to distinctive CHE growth hold seeds of potential challenges. A diminishing Christian population, but also one with diminished fealty to religion, is a direct threat. As CHE institutions then reach out to meet enrollment and faculty needs, they must expect an accelerated dilution of mission.

The general challenges to PHE and the particular challenges to identity institutions like CHE institutions are formidable. Nonetheless, CHE in recent decades has brought a surge of largely fresh identity institutions, providing some renewed energy to the private sector.

\section{Growing on the Margins: Global Christian Higher Education}

\section{Perry L. Glanzer}

Perry L. Glanzer is professor of educational foundations at Baylor University and a resident scholar with Baylor Institute for Studies of Religion, US. E-mail: Perry_Glanzer@baylor.edu.

Lor its first 600 years of existence, virtually all of West1 ern higher education was faith-based. Over the past two centuries, however, nation-states moved faith-based higher education to the margin, as they became the most powerful secularizing force affecting higher education. As a result, faith-based higher education has faced challenges from governments, but it also continues to experience growth on the margins when certain conditions are available.

What are the particular challenges facing the over I,IOO Christian colleges and universities in the world today? I define as "Christian" those universities or colleges that currently acknowledge and embrace a Christian identity (Catholic, Eastern Orthodox, or Protestant) and purpose in their mission statements, and shape aspects of their governance, curriculum, staffing, student body, and campus life in the light of that identity. I also define university to mean degree-granting institution with more than ecclesiastical or technical majors, and not a specialty institution, such as a theological seminary.

\section{Contem porary Challenges}

The most obvious challenge to Christian universities comes from the nationalization of higher education systems. In 